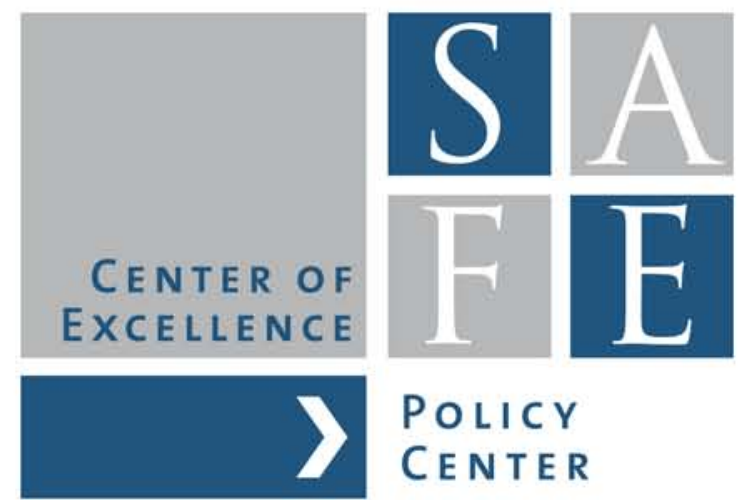

Prof. Dr. Brigitte Haar, LL.M. (Univ. Chicago)

\title{
Civil Liability of Credit Rating Agencies - Regulatory All-or-Nothing Approaches Between Immunity and Over-Deterrence
}

White Paper Series No. 1

Center of Excellence SAFE Sustainable Architecture for Finance in Europe A cooperation of the Center for Financial Studies and Goethe University Frankfurt 


\title{
Civil Liability of Credit Rating Agencies - Regulatory All-or-Nothing Approaches between Immunity and Over-Deterrence*
}

\author{
Prof. Dr. Brigitte Haar, LL.M. (Univ. Chicago) ${ }^{* *}$
}

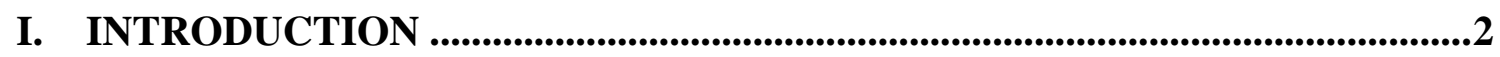
II. CIVIL LIABILITY OF CREDIT RATING AGENCIES IN A
COMPARATIVE PERSPECTIVE ......................................................................3
A. Contractual liability .....................................................................................................

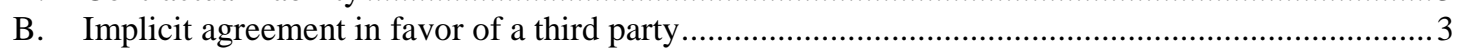

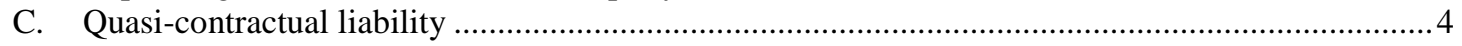
1. Special expertise and causation as a basis for liability under German law .............................. 4

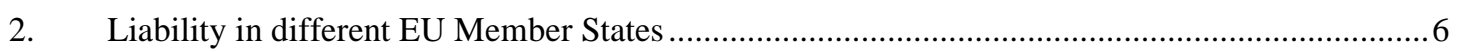
3. Reforms and Changes in US and Australian Law .............................................................. 7

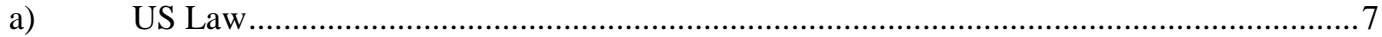

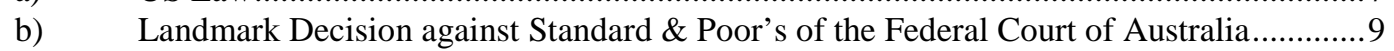

\section{PROCEDURAL FACILITATION AS A BASIS FOR LIABILITY IN ART.}

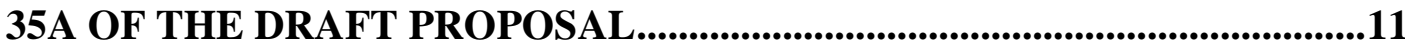

A. Art. 35a in the Draft Proposal......................................................................................... 11

B. Amendments by the Council of the European Union and by the European Parliament .................13

1. The General Approach of the Council of the European Union ..................................................13

2. The Amendments introduced by the European Parliament ..................................................... 14

\section{MAIN PARAMETERS OF AN EFFECTIVE LIABILITY RULE IN THE}

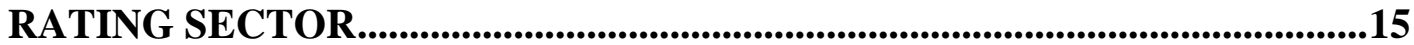

A. Excessive liability versus immunity - The causation issue .................................................... 16

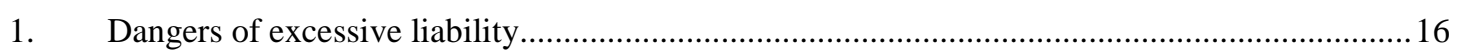

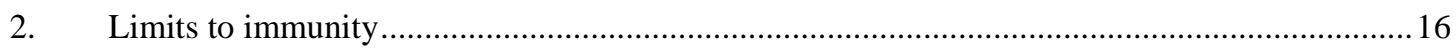

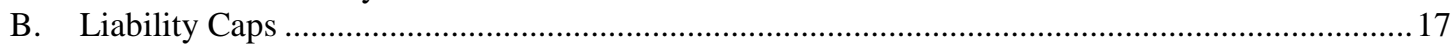

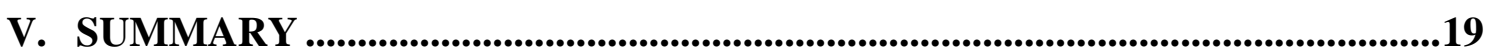

* This paper is also published in the University of Oslo Faculty of Law Legal Studies Research Paper Series No. 2013-02.

**Professor of Law at the House of Finance, Goethe-University, Frankfurt. 


\section{Introduction}

At Moody’s one analyst recalls rating a \$1 billion structured deal in 90 minutes. "People at the rating agencies used to say things like, 'I can't believe that we got comfortable with that deal,"” says Raynes [an individual employed by Moody’s in the 1990s]. ${ }^{1}$ Hand in hand with this situation went analysts' hope to be “...wealthy and retired by the time this house of cards falters..." because the CDO market appeared as a "monster". ${ }^{2}$ These quotes only give a slight idea of how bad a job the rating agencies did throughout the crisis, which resulted in quite a few law suits afterwards. ${ }^{3}$ At the same time, Fitch Investor Services insists that “...credit ratings, as opinions on relative ranking of vulnerability to default, do not imply or convey a specific statistical probability of default..."4

With the agencies' ratings moving to the center of the debate in the current sovereign debt crisis and the repercussions of wrong downgrades becoming greater, ${ }^{5}$ the liability issue is subject to an unprecedentedly intense regulatory debate in the rating industry. Only recently the European Commission has put forward a proposal for a regulation (CRA3) to amend and strengthen the 2009 version of the EU Rating Regulation, among other things imposing civil liability on the agencies. Art. 35a of the Commission's Draft Proposal introducing a mandatory civil liability of credit rating agencies has been one of the most controversial changes of this proposal. In order to arrive at an independent evaluation of this provision, one first has to take a look at the existing rules on civil liability of rating agencies under different legal systems (II.), before examining the provision under Art. 35a of the Draft Proposal more closely (III.) and arriving at

\footnotetext{
${ }^{1}$ S. Jones, When Junk Was Gold, Fin. Times (London), Oct. 17, 2008, p. 16 (available at http://www.ft.com/intl/cms/s/0/65892340-9b1a-11dd-a653-000077b07658.html\#axzz2D4DR7qn1).

${ }^{2}$ Securities Exchange Commission, Summary Report of Issues Identified in the Commission Staff's Examinations of Select Credit Rating (July 2008), p. 12 (http://www.sec.gov/news/studies/2008/craexamination070808.pdf).

${ }^{3}$ Abu Dhabi Commercial Bank v. Morgan Stanley \& Co., Inc., 651 F. Supp. 2d 155 (S.D.N.Y. 2009); for a preliminary decision of the Frankfurt Court of Appeals in Germany cf. Wochenüberblick, Betriebsberater (BB) 2010, p. 1482; Bathurst Regional Council v. Local Government Financial Services Pty Ltd (No. 5) [2012] FCA 1200.

${ }^{4}$ Fitch Investor Services, Understanding Credit Ratings, Limitations and Usage (available at http://www.fitchratings.com/jsp/general/RatingsDefinitions.faces?context=5\&detail=509\&context_ln=5\& detail_ln=500.

${ }^{5}$ For the example of the wrong downgrade of France cf. BBC News, ' $S \&$ P accidentally announces downgrade of French debt', BBC News of Nov. 10, 2011 (available at http://www.bbc.co.uk/news/business-15686580).
} 
conclusions how to analyze the liability matter in a more differentiated way and how to possibly improve the Proposal (IV.).

\section{Civil Liability of Credit Rating Agencies in a Comparative Perspective}

\section{A. Contractual liability}

In the European member states there is no specific legislation governing contracts between issuers and credit rating agencies, so that the general rules of contract law will apply in full. As a result, one has to overcome some major obstacles in order to hold rating agencies liable for breach of contract. First of all, for the most relevant scenario of an investor claiming damages he suffered from a flawed rating there is no immediate contractual relation between him and the potential addressee of such a contractual claim, i.e. the rating agency rating the issue in question. As far as any contractual claim of the issuer against the credit rating agency is concerned, the underlying contracts always include an exclusion of liability in favor of the agency. Only under the French Loi de regulation bancaire et financière ("Law regulating banking and finance" or "RBF Act”) ${ }^{6}$, enacted on October 23, 2010, these contractual clauses will be deemed null and void. ${ }^{7}$ In light of these hurdles, one has to draw on specific doctrinal exceptions in order to lay a basis for a contractual claim.

\section{B. Implicit agreement in favor of a third party}

Under German law the debate on contractual liability of rating agencies centers on the potential existence of an implicit agreement between the issuer and the rating agency so as to protect the investors as third parties. The prevailing doctrine states certain requirements that have to be met in order to be able to rely on such a contractually based claim, so that the potential range of those potentially liable in contract does not grow to an unreasonable extent. That is why the claimant of such a contractual claim has to find him-/herself in a creditor like position. In the case of the rating agencies the rating aims at the capital market and the investor, who is supposed to take it into account for his investment decision. At the same time, however, the interests of the

\footnotetext{
${ }^{6}$ Loi n ${ }^{\circ}$ 2010-1249 du 22 octobre 2010 de régulation bancaire et financière (available at http://www.legifrance.gouv.fr/affichTexte.do;jsessionid=D180F17E5A1D3FA8F1211F195C5004F6.tpdj o09v_2?cidTexte=JORFTEXT000022940663\&categorieLien=id\#JORFSCTA000022940671).

${ }^{7}$ Art. L. 544-6. - Les clauses qui visent à exclure la responsabilité des agences de notation de crédit mentionnées à l'article L. 544-4 sont interdites et réputées non écrites.
} 
investor and the issuer are not aligned. Whereas the issuer is interested in the highest possible rating, the investor would prefer a lower rating in the interest of a cheaper entry-level price. Therefore, the contractual conceptualization of the underlying relationships may seem a little far-fetched from a doctrinal point of view.

Hand in hand with this interest analysis goes a second requirement for a claim based on an implicit agreement in favor of the investor that seems problematic, that is the investor's specific vulnerability. Such a vulnerability is absent in the presence of another potentially liable party. In the case of investor losses it is generally the issuer who is insolvent and unable to satisfy his/her investors' claims. If now the investor can have recourse to the rating agency, there is no denying the fact that there is a danger that the insolvency risk is shifted to the rating agency. ${ }^{8}$

\section{Quasi-contractual liability}

1. Special expertise and causation as a basis for liability under German law

Without a contractually based relationship between the rating agency and the investor, the role of the rating agency as an expert in the capital market enters into play as a circumstance possibly constituting the basis for quasi-contractual liability. Under German law § 311 para. 3 sent. 2 of the German Civil Code explicitly states someone’s liability, if he or she inspires confidence, thus favorably influencing contract negotiations or the conclusion of a contract. In its narrow sense, the legal definition of the pre-contractual liability under $\S 311$ para. 3 sent. 2 of the German Civil Code suggests some immediate contact between the party held liable and the claimant. According to the German case law on the legal liability for statements in the prospectus such a specific basis for investors' typical reliance on the misstatements is even required for liability in this more common scenario. ${ }^{9}$

That is why one would have to state the factual requirements for the liability of credit rating agencies more loosely and primarily base it on the intermediary function of rating agencies as gatekeepers of the capital market. ${ }^{10}$ In fact, the success of the agencies’

\footnotetext{
${ }^{8}$ For the danger of such a risk shifting see R.Lemke, Haftungsrechtliche Fragen des Ratingwesens - ein Regelungsproblem? p. 82 and following (Peter Lang, 2000).

${ }^{9}$ BGHZ 77, 172, 176 f.; 111, 314, 319 f.; BGH Neue Juristische Wochenschrift-Rechtsprechungs-Report 1992, 879, 883.

${ }^{10}$ For such a more loose basis of a pre-contractual liability based on reliance cf. W.Canaris, Die

Reichweite der Expertenhaftung gegenüber Dritten, 163 Zeitschrift für das gesamt Handelsrecht p. 206,
} 
business model depends on network effects that make personal contacts unnecessary and are key to their fundamental self-interest. Another possible basis for a claim against rating agencies under German law not requiring any contractual ties between the parties would, of course, be tort liability under $\S 826$ of the German Civil Code. This provision reaches beyond any particular category of gatekeepers and served as a basis for auditor and lawyer liability for example in the past. ${ }^{11}$ On the other hand, tort liability under $\S$ 826 of the Civil Code requires the showing of a violation of public policy, scienter, and reliance, so that it will only lead to success in cases of clear mistakes, if the information is not verified by the defendant despite concerns on his part that he has ignored in an unscrupulous manner, in order to pursue his financial interests and without any regard for the investor's interests. ${ }^{12}$

In addition to the basis of trust outlined above, issues of causation remain to be resolved under German law in order to establish a valid claim against a rating agency. These issues are very similar to the discussion about causation between a misleading statement and an investment decision in different liability cases based on a prospectus or ad hoc disclosure rules. In prospectus liability cases based on general civil law the courts start from the presumption that the securities would not have been acquired because the investor would have acted according to the given information, if no misleading statement had been made at the time of the acquisition ("aufklärungsrichtiges Verhalten”).

On the other hand, causation required under ad hoc disclosure rules has differed considerably from this far-reaching presumption. In these cases claims for violation of the obligation to disclose current reports (ad-hoc-publicity), the delay in the disclosure of insider information ( $\S 37 \mathrm{~b}$ Wertpapierhandelsgesetz), and the publication of

\footnotetext{
220 and following, 229 (1999), 229; P. Krebs, Sonderverbindung und außerdeliktische Schutzpflichten, p. 557 (Beck, 2000); D. Looschelders, Schuldrecht Allgemeiner Teil, Note 218 (8th ed., Franz Vahlen 2010); M. Plötner, Die Rechtsfigur des Vertrags mit Schutzwirkung für Dritte und die sogenannte Expertenhaftung, p. 286 and following (Duncker \& Humblot 2003); for the qualification of rating agencies as gatekeepers cf. J. Coffee, Gatekeepers; The Role of the Professions in Corporate Governance, p. 2 (Oxford University Press 2006); A. Peters, Die Haftung und die Regulierung von Rating-Agenturen, p. 119 and following (Nomos 2001); for a different view cf. F. Partnoy, How and Why Credit Rating Agencies Are Not Like Other Gatekeeper, p. 59, 60 and following, in: Y. Fuchita and R. Litan (eds.), Financial Gatekeepers; Can They Protect Investors? (Brookings Institution Press 2006).

${ }^{11}$ For auditor liability see BGH Neue Juristische Wochenschrift 1956, 1595; for lawyer liability see BGH Neue Juristische Wochenschrift 1972, 678, 680.

${ }^{12}$ BGH Neue Juristische Wochenschrift 1991, 3282, 3283; for further references see H. Hirte, Berufshaftung, p. 64-65 (C.H.Beck 1996).
} 
misleading insider information (§ 37c Wertpapierhandelsgesetz) are at stake. In these instances the German Federal Court of Justice used to require proof of actual reliance, refusing to adopt any reasoning along the lines of the American fraud-on-the market theory. ${ }^{13}$ Very recently, on the occasion of the IKB case the Court changed its case law presuming relevance of information for securities prices in highly volatile markets. Therefore, the causation issue under German law is far from clear. The situation appears to be similar under current Dutch law as a result of the Dutch Supreme Court World Online decision. ${ }^{14}$ In a narrow sense the requirements for quasi-contractual liability are not met in the rating scenario under discussion. At the same time, there are loopholes that could serve as points of departure to introduce some kind of gatekeeper liability of rating agencies in analogy to liability for misstatements in a prospectus based on general German civil law. ${ }^{15}$

\section{Liability in different EU Member States}

Credit rating agencies' liability for flawed ratings has been on the agenda in quite a few other EU Member States and the debate has intensified lately against the background of the proposal of a civil liability rule based on the amendment of the EU rating regulation. The French legislator, for instance, has already adopted a liability framework somewhat similar to the one envisioned by the Draft Proposal. Under Art. L. 544-5 of the Monetary and Financial Code credit agencies can be held liable for damages either in tort or in quasi-tort by clients and third parties, if they are at fault or neglect to implement the provisions of the EU rating regulation. ${ }^{16}$ For English law Section 90 of

13 ComROAD I and II BGH, Neue Zeitschrift für Gesellschaftsrecht 2007, 345 and 346; ComROAD III $B G H$, Neue Zeitschrift für Gesellschaftsrecht 2007, 269; ComROAD IV BGH, Zeitschrift für Wirtschaftsund Bankrecht 2007, 1557; ComROAD V BGH Neue Zeitschrift für Gesellschaftsrecht 2007, 708; ComROAD VI BGH, Neue Zeitschrift für Gesellschaftsrecht 2008, 382, 383; ComROAD VII BGH, Neue Zeitschrift für Gesellschaftsrecht 2008, 385; ComROAD VIII BGH, Neue Zeitschrift für Gesellschaftsrecht 2008, 386; see also J. Hennrichs, in: Festschr. Hadding, p. 875, 891; T. Möllers, Kausalität für den Differenzschaden und uferlose Haftungsausdehnung-Comroad I - VIII, Neue Zeitschrift für Gesellschaftsrecht 2008, 413; with reference to the liability issue in the rating sector e.g. K.-P. Berger and M. Stemper, Haftung von Ratingagenturen gegenüber Anlegern, Zeitschrift für Wirtschafts- und Bankrecht 2010, 2289, 2294; not quite precisely however G. Wildmoser, J. Schiffer and B. Langoth, Haftung von Ratingagenturen gegenüber Anlegern, Recht der Internationalen Wirtschaft 2009, 657, 664.

${ }^{14}$ VEB e.a. / World Online e.a., Hoge Raad, November 27, 2009, JOR 2010/43; for a further analysis of this decision cf. B. de Jong, Liability for Misrepresentation - European Lessons on Causation from the Netherlands, 8 European Company and Financial Law Review 364-366 (2011).

${ }^{15} \mathrm{~B}$. Haar, Haftung für fehlerhafte Ratings - Ein neuer Baustein für ein verbessertes Regulierungsdesign für Ratingagenturen? Neue Zeitschrift für Gesellschaftsrecht 2010, 1281, 1284-1285.

${ }^{16}$ Art. L. 544-5. - Les agences de notation de crédit mentionnées à l'article L. 544-4 engagent leur responsabilité délictuelle et quasi délictuelle, tant à l'égard de leurs clients que des tiers, des conséquences dommageables des fautes et manquements par elles commis dans la mise en œuvre des obligations 
the Financial Services and Markets Act 2000 applying to misstatements in the prospectus of the listing particulars, and the implementing legislation is under discussion in the literature as a yet unclear basis to establish a gatekeeper liability. ${ }^{17}$ At the same time, other authors refer to the common law "promissory estoppel” doctrine ${ }^{18}$ or to tort law ${ }^{19}$ as possible bases for liability claims against rating agencies in order to avoid the privity of contract limitations. ${ }^{20}$

\section{Reforms and Changes in US and Australian Law}

\section{a) US Law}

Prior to the enactment of the Dodd-Frank Act ${ }^{21}$, US case law centered on an argument different from privity of contract in order to deny rating agencies' liability, that is the First Amendment defense. ${ }^{22}$ In order to avoid liability, rating agencies generally argued to be members of the press. ${ }^{23}$ Therefore ratings had to be looked at as opinions to be protected under a heightened malice standard. ${ }^{24}$ Despite this general protection, recently after the financial crisis there were unsuccessful attempts to raise this defense, when the agency was found to have been an active participant in structuring the proposed

définies dans le règlement (CE) n 1060/2009 du Parlement européen et du Conseil, du 16 septembre 2009, précité.

${ }^{17}$ Financial Services and Markets Act 2000 (c.8); Schedule 10 adopted under section 90(2) and (5) of the FSMA; FSA Prospectus Rules (PR) 5.5 (for prospectuses); FSMA 2000 (Official Listing of Securities) Regulations 2001 (SI 2001/2956), reg. 6 (for listing particulars); C. Gerner-Beuerle, Underwriters, Auditors, and other Usual Suspects: Elements of Third Party Enforcement in US and European Securities Law, 6 European Company and Financial Law Review 493-499 (2009).

${ }^{18}$ For the necessary requirements cf. Section 90 of the Second Restatement of Contracts which states:”A promise which the promisor should reasonably expect to induce action or forbearance on the part of the promisee or a third person and which does induce such action or forbearance is binding if injustice can be avoided only by the enforcement of the promise.” (Restatement [Second] of Contracts § 90 [1981]); see e.g. K. Nelson, Rough Waters for the Ratings Companies: Should the Securities Ratings Companies Be Held Liable for Investor Reliance in the Wake of the Real Estate Meltdown of 2007/2008? 63 U. Miami L. Rev. 1191-1196 (2009); A. Miglionico, Enhancing the Regulation of Credit Rating Agencies, in Search for a Method, p. 72-74, University of London, The Center for Financial and Management Studies, Research Paper 089_DP105 (July 2012), http://www.cefims.ac.uk/cgi-bin/research.cgi?id=99.

${ }^{19}$ O. v. Schweinitz, Rating Agencies: Their Business, Regulation, and Liability under U.S., U.K., and German Law (Unlimited Publishing 2007).

${ }^{20}$ A. Miglionico, Enhancing the Regulation of Credit Rating Agencies, in Search for a Method, p. 72-74, University of London, The Center for Financial and Management Studies, Research Paper 089_DP105 (July 2012), http://www.cefims.ac.uk/cgi-bin/research.cgi?id=99.

${ }^{21}$ Dodd-Frank Wall Street Reform and Consumer Protection Act, Pub. L. 111-203 (2010).

${ }^{22}$ For the prevailing case law on the protection of rating agencies under the First Amendment see C. Kettering, Securitization and its Discontents: The Dynamics of Financial Product Development, 29 Cardozo L. Rev. 1553, 1689 and following (2008); C. Hill, Regulating the Rating Agencies, 82 Wash. U. L. Qu. 43, 56 and following (2004); T. Nagy, Credit rating agencies and the First Amendment: applying constitutional journalistic protections to subprime mortgage litigation, 94 Minn. L. Rev. 140-167 (2009).

${ }^{23}$ See e.g. T. Pate, Triple-A ratings stench: may the credit rating agencies be held accountable? 14 Barry L. Rev. 25, 45 (2010).

${ }^{24}$ New York Times Co. v. Sullivan, 376 U.S. 254 (1964); in the rating sector see Dun \& Bradstreet, Inc. v. Greenmoss Builders, Inc., 472 U.S. 749, 753 (citing Sullivan, 376 U.S. 254) 
transaction $^{25}$ or to have been subject to conflicts of interest resulting from this role or from the fee structure underlying this issue and amounting to a contingent fee and the resulting improper motivation. ${ }^{26}$ In the latter case the rating was only paid if the rating was actually used in the offering.

In light of these obstacle to plaintiffs bringing suits against credit rating agencies, in the aftermath of the financial crisis the US legislator introduced a private cause of action in the Dodd Frank Act under which investors can sue credit rating agencies for knowingly or recklessly failing to conduct a reasonable investigation of facts or for failing to obtain an analysis from an independent source. ${ }^{27}$ More importantly, Dodd Frank included a repeal of Rule 436(g) of Securities Act of 1933, thus subjecting rating agencies to “expert liability” for misleading statements in registration statements under Section 11 of the 1933 Securities Act. Under such an expert liability according to Section 11 an expert is held liable except in cases where he shows that he met the due diligence requirement, i.e. that he had, “....after reasonable investigation, reasonable ground to believe and did believe...” that there were no misstatements or omissions of material facts in the portions of the registration statement he prepared. ${ }^{28}$ The implementation of this newly created liability turned out to be difficult and the repeal does not have the previously hoped for effect as regulatory behavior control. The major rating agencies refused to have their ratings included in registration statements, bringing about a virtual standstill in the market for asset-backed securities. ${ }^{29}$ As a result, the SEC found itself forced to publish a no-action letter to avoid enforcement actions so long as the amendment could not be effectively implemented on July 22, 2010, which was to be applied until January 24, 2011. Half a year later, on July 20, 2011, the removal of this expert liability introduced for rating agencies in the Dodd Frank Act was approved by

\footnotetext{
${ }^{25}$ Cal. Pub. Employees' Retirement Sys. v. Moody's Corp., No. CGC-09-490241 (Cal. App. Dept' Super. Ct. July 9, 2009) § 47, available at http://online.wsj.com/public/resources/documents/calpers.pdf, at p. 38; for a detailed analysis cf. N. Ellis, L. Fairchild and F. D’Souza, Conflicts of interest in the Credit Rating Industry after Doddd-Frank: Continued Business as Usual? 17 Stan. J.L. Bus. \& Fin. 175, 203-210 (2012); D. Grais and K. Katsiris, Not „The World's Shortest Editorial“: Why the First Amendment Does not Shield the Rating Agencies from Liability for Over-Rating CDOs, Bloomberg L. Rep., Nov. 12, 2007, p. $40,41$.

${ }^{26}$ Abu Dhabi Commercial Bank v. Morgan Stanley \& Co., 651 F. Supp. 2d 155, 166-167, 179-180 (S.D.N.Y. 2009).

${ }^{27}$ Dodd Frank § 933.

${ }^{28}$ Dodd Frank/Securities Act 15 U.S.C. $\S 77 \mathrm{k}$ (b)(3)(B)(i).

${ }^{29}$ B. Brownlow, Rating Agency Reform: Preserving the Registered Market for Asset-Backed Securities, 15 N.C. Banking Inst. 111 (2011).
} 
the US House Financial Services Committee in response to the threat of a market freeze. $^{30}$

\section{b) Landmark Decision against Standard \& Poor's of the Federal Court of Australia}

At the other end of the world quite opposite changes have come about in the field of the liability of rating agencies. In Bathurst Regional Council v. Local Government Financial Services Pty Ltd (No. 5) ${ }^{31}$ the Federal Court of Australia has overcome some of the well-known obstacles to civil liability of rating agencies as stated above, holding Standard \& Poor's liable for its triple-A rating of complex financial products in 2006. In the underlying lawsuit the financial advisor Local Government Financial Services (LGFS), the investment bank ABN Amro, and Standard \& Poor's were found liable for the losses suffered by thirteen local councils arising from the sale and purchase of a structured financial product known as the Rembrandt 2006-3 constant proportion debt obligation (CPDO). The councils based their claim on the contention of misleading and deceptive conduct with regard to financial products on the part of Standard \& Poor's. As it has been common in the liability cases in the US, Standard \& Poor's again referred to the disclaimers in the pre-sale and post-sale reports asserting that a rating is a statement of opinion. ${ }^{32}$ Justice Jayne Jagot, however, refused to bring to bear the protection of the freedom of expression, so that rating agencies would be able to escape liability, distinguishing between this case and the relevant US case law, thus laying a basis for holding Standard \& Poor’s liable for misrepresenting that its rating was based on reasonable grounds and the product of the exercise of reasonable care. ${ }^{33}$

Against this background the court looked at the misrepresentation claims raised against Standard \& Poor's by both the LGFS and the councils. According to the court, the basis for Standard \& Poor’s misleading and deceptive conduct was the representation that this

\footnotetext{
${ }^{30}$ P. Mattingly, House Panel Backs Stripping Dodd-Frank Credit-Rater Liability, Bloomberg, July 20, 2011, available at: http:/www.bloomberg.com/apps/news?pid=munievents\&sid=anL1NDURCLRg. ${ }^{31}$ [2012] FCA 1200 (5 November 2012), available at: http://www.imf.com.au/pdf/Judgment\%20of\%20Jagot\%20J\%20dated\%205\%20November\%202012\%20r e_\%20Local\%20Government\%20Financial\%20Services\%20Pty\%20Ltd\%20\%28No\%205\%29.pdf

${ }^{32}$ Bathurst Regional Council v. Local Government Financial Services Pty Ltd (No. 5), [2012] FCA 1200 (5 November 2012), Notes 2416-2418, available at: http://www.imf.com.au/pdf/Judgment\%20of\%20Jagot\%20J\%20dated\%205\%20November\%202012\%20r e_\%20Local\%20Government\%20Financial\%20Services\%20Pty\%20Ltd\%20\%28No\%205\%29.pdf

${ }^{33}$ Bathurst Regional Council v. Local Government Financial Services Pty Ltd (No. 5), [2012] FCA 1200 (5 November 2012), Notes 2800-2802, notes 2543, 2800-2803, available at: http://www.imf.com.au/pdf/Judgment\%20of\%20Jagot\%20J\%20dated\%205\%20November\%202012\%20r e_\%20Local\%20Government\%20Financial\%20Services\%20Pty\%20Ltd\%20\%28No\%205\%29.pdf
} 
opinion had been reached on a reasonable basis and as a result of an exercise of reasonable care. ${ }^{34}$ Pointing out the modeling inputs used by Standard \& Poor's, which would not have been used by any reasonable rating agency, and the underlying assumptions substantially more favorable to the performance of the CPDOs than the actual economic conditions, the court was satisfied by the evidence. The same applied to the knowledge on the part of Standard \& Poor's that its representation was not true. Since Standard \& Poor's failed to show a lack of due care and skill as well as unreasonable reliance on the triple-A rating on the part of the councils, the court found that Standard \& Poor's rating was misleading and deceptive. ${ }^{35}$

The main issue about the negligence claim also raised against Standard \& Poor's was the question whether the rating agency owed a duty of care to potential buyers of the Rembrandt notes. ${ }^{36}$ Similarly to the argument made in the context of the privity of contract mentioned above, the Australian judge focuses on the primary goal of the issuer, which is to obtain the rating for communication purposes with regard to the investors as a basis for the latter's investment decisions. ${ }^{37}$ In contrast to the case law in the different member states cited above, as for the necessary causation the Australian court considered it sufficient to show that the triple-A rating was besides the LGFS's recommendation one of two principal reasons for the councils' agreement to invest in the Rembrandt notes. ${ }^{38}$ In summary, in Bathurst Regional Council v. Local Government Financial Services Pty Ltd the Federal Court of Australia has overcome well-known hurdles to lay a legal foundation for the civil liability of rating agencies, so that more

\footnotetext{
${ }^{34}$ Bathurst Regional Council v. Local Government Financial Services Pty Ltd (No. 5), [2012] FCA 1200 (5 November 2012), Notes 2416-2418, available at: http://www.imf.com.au/pdf/Judgment\%20of\%20Jagot\%20J\%20dated\%205\%20November\%202012\%20r e_\%20Local\%20Government\%20Financial\%20Services\%20Pty\%20Ltd\%20\%28No\%205\%29.pdf.

${ }^{35}$ Bathurst Regional Council v. Local Government Financial Services Pty Ltd (No. 5), [2012] FCA 1200 (5 November 2012), Notes 1833-1840, available at: http://www.imf.com.au/pdf/Judgment\%20of\%20Jagot\%20J\%20dated\%205\%20November\%202012\%20r e_\%20Local\%20Government\%20Financial\%20Services\%20Pty\%20Ltd\%20\%28No\%205\%29.pdf.

${ }^{36}$ Bathurst Regional Council v. Local Government Financial Services Pty Ltd (No. 5), [2012] FCA 1200 (5 November 2012), Notes 2455-2460, available at: http://www.imf.com.au/pdf/Judgment\%20of\%20Jagot\%20J\%20dated\%205\%20November\%202012\%20r e_\%20Local\%20Government\%20Financial\%20Services\%20Pty\%20Ltd\%20\%28No\%205\%29.pdf.

${ }^{37}$ Bathurst Regional Council v. Local Government Financial Services Pty Ltd (No. 5), [2012] FCA 1200 (5 November 2012), Note 2455, available at: http://www.imf.com.au/pdf/Judgment\%20of\%20Jagot\%20J\%20dated\%205\%20November\%202012\%20r e_\%20Local\%20Government\%20Financial\%20Services\%20Pty\%20Ltd\%20\%28No\%205\%29.pdf.

${ }^{38}$ Bathurst Regional Council v. Local Government Financial Services Pty Ltd (No. 5), [2012] FCA 1200 (5 November 2012), Note 2458, available at: http://www.imf.com.au/pdf/Judgment\%20of\%20Jagot\%20J\%20dated\%205\%20November\%202012\%20r e_\%20Local\%20Government\%20Financial\%20Services\%20Pty\%20Ltd\%20\%28No\%205\%29.pdf.
} 
litigation and new actions can be expected to follow this landmark decision not only in Australia, but at least in those countries where this type of products was mis-rated as well. $^{39}$

\section{Procedural facilitation as a basis for liability in Art. 35a of the European Commission's Draft Proposal}

\section{A. Art. 35a of the Draft Proposal}

In light of the serious flaws in the Big Three's ratings and their contribution to the financial crisis as well as their involvement in the sovereign debt crisis, in its CRA3 Draft Proposal the European Commission included a very strict liability rule in Art. 35a in order to avoid the shortcomings of existing liability rules as just put forward and to ensure the accountability of rating agencies for their ratings. ${ }^{40}$ This becomes apparent from the following key points of this liability provision.

As a starting point, under Art. 35a para. 1 of the Draft Proposal any “infringement... listed in Annex III having an impact on a credit rating on which an investor has relied when purchasing a rated instrument” will be suitable to trigger liability of the “... credit rating agency for any damage caused to the investor". ${ }^{41}$ Without more these requirements do not necessarily facilitate the pursuit of legal remedies for investors because the investor is entitled to damages, only if the infringement has had an impact on the rating and he/she has relied on this rating and there has been causation between the infringement and the investor's damages (Art. 35a para. 1 of the Draft Proposal). As has become apparent at the example of the different legal systems looked at above, these additional requirements have proved to be serious obstacles to rating agencies' liability. That is why the procedural facilitation that was included in Art. 35a paras. 2-4 of the Draft Proposal turns to be the actual trigger of liability. ${ }^{42}$

\footnotetext{
${ }^{39}$ P. Durkin and H. Low, IMF talks of new wave of litigation, Australian Financial Review, November 7, 2012, p. 14; D. Fickling and M. Robinson, McGraw-Hill Plummets After Australian Court Ruling, Bloomberg, November 5, 2012, available at: http://www.bloomberg.com/news/2012-11-04/s-p-foundliable-by-australian-court-for-misleading-ratings.html; Author not named, Australian Court issues landmark judgment against S\&P, Telegraph, November 5, 2012, available at: http://www.telegraph.co.uk/finance/newsbysector/banksandfinance/9655922/Australian-court-issueslandmark-judgment-against-SandP.html.

${ }^{40}$ COM (2011) 747 fin.

${ }^{41}$ COM (2011) 747 fin. p. 33.

${ }^{42}$ COM (2011) 747 fin. p. 33.
} 
What is most important is the shift in the burden of proof according to Art. 35a para. 4, so that it is sufficient for the investor to establish “...facts from which it may be inferred that a credit rating agency has committed any of the infringements...” and the burden is on the credit rating agency to prove that it has not committed that infringement or that that infringement did not have an impact on the issued credit rating”. At the bottom line, under this provision rating agencies have to provide proof of the flawlessness of their ratings, eventually putting them under pressure to disclose their methods and modeling inputs. $^{43}$. This is very much at odds with the limits of disclosure duties as stated in the EU Rating Regulation of 2009, which should not jeopardize trade secrets nor impede innovation. ${ }^{44}$ Such a disclosure might eliminate competition for the best rating methods, ${ }^{45}$ thus thwarting the desired goal of the European Commission to strengthen competition and revealing the structural problems in the rating sector. ${ }^{46}$ What is even more detrimental to competition, when it comes to the implementation of such a farreaching liability rule, is its potential deterring effect on market entry of new competitors, who will shy away from these high liability risks. In addition, far-reaching liability will have a chilling effect on capital markets because, as has been seen in the aftermath of the passage of Dodd Frank and the expert liability imposed on rating agencies, the latter may be reluctant to rate some financial instruments at all. ${ }^{47}$ Looking at the impact of such a liability rule on the Common Market in a more general respect, even more serious flaws of this rule become apparent. Since jurisdiction in the potential liability cases would lie with the member states' courts, member states' reputation would come into play as regards the effective regulation of financial markets despite

\footnotetext{
${ }^{43}$ S. Fischer, Haftungsfragen des Ratings, p. 67 and following (Dr. Kovac 2007); K. Serfing and A. Pries, Möglichkeiten und Grenzen des Rating, Die Bank 1990, 381; E. Vetter, Rechtsprobleme des externen Ratings, Zeitschrift für Wirtschafts- und Bankrecht 2004, 1701, 1707.

${ }^{44}$ EU Regulation (EC) No 1060/2009 on credit rating agencies of 16.9.2009, Consideration 25, OJ EU L 302, p. 3.

${ }^{45}$ B. Haar, Nachhaltige Ratingqualität durch Gewinnabschöpfung? Zur Regulierung und ihrer Implementierung im Ratingsektor, 21 Zeitschrift für Bankrecht und Bankwirtschaft 177, 182 (2009).

${ }^{46}$ EU Commission, Regulation of the European Parliament and of the Council to Amending Regulation (EC) No 1060/2009 on credit rating agencies, COM (2011) 747 fin., p. 5, 12.

${ }^{47}$ See above II.C.3.a); with regard to the liability rule included in Art. 35a of the Draft Proposal see e.g. Bundesverband der Deutschen Industrie, Deutsches Aktieninstitut, Verband Deutscher Treasurer; Kommentar von DAI, BDI und VDT zum Bericht des Ausschusses für Wirtschaft und Währung im Europäischen Parlament zum Vorschlag der Europäischen Kommission für eine „Verordnung des Europäischen Parlaments und des Rates zur Änderung der Verordnung (EG) Nr. 1060/2009 über Ratingagenturen“, Frankfurt M., Berlin, 14 September 2012, available at http://www.dai.de/internet/dai/dai-20.nsf/0/6CE579BD07BD1212C1257A8B002346F7/\$FILE/C4C64729EB04C02AC1257A8B002346D7.p df?openelement\&cb_content_name_utf=2012-9-14\%20DAI-BDIVDT\%20Kommentar\%20zum\%20ECON-Bericht\%20CRA\%20III.pdf; R. von Rosen, Die Pläne der EU-Kommission zur Regulierung der Ratingagenturen schaffen nur neue Probleme, Süddeutsche Zeitung, April 13, 2012, p. 18.
} 
EU-wide regulation. In case of a member state taking a tough stance, the negative consequences for its capital market are self-evident and therefore questions as to the impact on an open market for capital in the European Union may be raised. ${ }^{48}$ Looking at the reversal of the burden of proof more generally, in light of the complexity of the rating regulations, an investor will always find some questionable practice to exploit as an infringement, and under the Draft Proposal the rating agencies would then have to carry the burden of proof to establish their innocence.

\section{B. Amendments by the Council of the European Union and by the European Parliament}

1. The General Approach of the Council of the European Union

Therefore it comes as no surprise that this stringent liability rule has encountered incisive criticism not only from interest-groups, but also from the other European institutions involved in the legislative process, which have therefore presented alternative amendments. In its general approach on the subject of the Draft Proposal of May 25, 2012 the European Council provided for a considerable alleviation of the liability rule conceived by the European Commission in the Draft Proposal. ${ }^{49}$ In effect, the general approach does away with the reversal of the burden of proof, so that under this approach damages may be claimed only if the investor or issuer establishes an infringement intentionally or grossly negligently committed by an agency that has an impact on a rating, reasonable reliance on that rating for an investment decision and causation between the infringement and the damages suffered by him. ${ }^{50}$ Furthermore, within reasonable limits liability can be limited in advance under Art. 35a para. 5 of the general approach. By giving member states some leeway to interpret open-ended terms of the liability rule in accordance with the applicable national law in Art. 35a para. 6 of the common approach, indirect reference is made to the national laws outlined above.

\footnotetext{
${ }^{48}$ For similar concerns about potential consequences of fragmentation of European supervision cf. M. Lamandini, Credit Rating Agencies (CRAs) and European Regulation, 6 European Company Law 131, 133 (2009).

${ }^{49}$ Council of the European Union, Proposal for a Regulation of the European Parliament and of the Council amending Regulation (EC) No 1060/2009 on credit rating agencies, General approach, Interinstitutional File 2011/0361 (COD), Brussels, 25 May 2012, available at http://register.consilium.europa.eu/pdf/en/12/st10/st10452.en12.pdf.

${ }^{50}$ Council of the European Union, Proposal for a Regulation of the European Parliament and of the Council amending Regulation (EC) No 1060/2009 on credit rating agencies, General approach, Interinstitutional File 2011/0361 (COD), Brussels, 25 May 2012, p. 44-45, available at http://register.consilium.europa.eu/pdf/en/12/st10/st10452.en12.pdf.
} 
As a result, the shortcomings of the traditional national liability provisions, such as the difficulties of proof and the causation issue remain unresolved. ${ }^{51}$

2. The Amendments introduced by the European Parliament

This alleviation of liability in the general approach of the Council of the European Union of May 25, 2012 was again modified and a stricter version was proposed in its report by the Committee on Economic and Monetary Affairs on the Draft Proposal of August 23, 2012. ${ }^{52}$ As becomes clear from this report, the European Parliament and the Legal Affairs Committee in particular have favored the inclusion of common civil liability rules for deliberate and negligent infringements of the rules of the EU rating regulation. At the same time, they consider some changes necessary to ensure an appropriate balance between the different stakeholders involved. ${ }^{53}$ This is why the Committee on Legal Affairs proposes in its amendments of Art. 35a that the reversal of the burden of proof on credit rating agencies should be struck down. ${ }^{54}$ In order to ensure coherence between civil liability proceedings and the existing supervisory measures of ESMA, the Committee on Legal Affairs also suggests that the court seized demand the opinion of ESMA and take into consideration any formal ESMA decision (Amendment Art. 35a para. 3). ${ }^{55}$ As far as the causation issue is concerned, the report considers a reversal of burden of proof inappropriate, so that under the Amendment to Art. 35a para. 4 the burden shall be on the investor to prove causation between the infringement and the impact on the issued rating

\footnotetext{
${ }^{51}$ See above II.C.1. and 2.

52 European Parliament, Committee on Economic and Monetary Affairs, Report on the proposal of August 23, 2012. for a regulation of the European Parliament and of the Council amending Regulation (EC) No 1060/2009 on credit rating agencies (COM(2011)0747 - C7-0420/2011 - 2011/0361(COD)), August 23, 2012, A7-0221/2012, available at http://www.europarl.europa.eu/sides/getDoc.do?pubRef=//EP//NONSGML+REPORT+A7-2012-0221+0+DOC+PDF+V0//EN.

${ }^{53}$ European Parliament, Committee on Economic and Monetary Affairs, Report on the proposal of August 23, 2012. for a regulation of the European Parliament and of the Council amending Regulation (EC) No 1060/2009 on credit rating agencies (COM(2011)0747 - C7-0420/2011 - 2011/0361(COD)), August 23, 2012, A7-0221/2012, p. 82, available at http://www.europarl.europa.eu/sides/getDoc.do?pubRef=-//EP//NONSGML+REPORT+A7-20120221+0+DOC+PDF+V0//EN.

${ }^{54}$ European Parliament, Committee on Economic and Monetary Affairs, Report on the proposal of August 23, 2012. for a regulation of the European Parliament and of the Council amending Regulation (EC) No 1060/2009 on credit rating agencies (COM(2011)0747 - C7-0420/2011 - 2011/0361(COD)), August 23, 2012, A7-0221/2012, p. 83, available at http://www.europarl.europa.eu/sides/getDoc.do?pubRef=-//EP//NONSGML+REPORT+A7-20120221+0+DOC+PDF+V0//EN.

${ }^{55}$ European Parliament, Committee on Economic and Monetary Affairs, Report on the proposal of August 23, 2012. for a regulation of the European Parliament and of the Council amending Regulation (EC) No 1060/2009 on credit rating agencies (COM(2011)0747 - C7-0420/2011 - 2011/0361(COD)), August 23, 2012, A7-0221/2012, p. 83 and 84, available at http://www.europarl.europa.eu/sides/getDoc.do?pubRef=-//EP//NONSGML+REPORT+A7-20120221+0+DOC+PDF+V0//EN.
} 
and between the rating and his investment decision. ${ }^{56}$ Furthermore, the report includes two amendments aiming for the consideration of national laws and courts in liability cases. The amendment to Art. 35a para. 5a (new) declares “...the civil liability regime of the Member State in which the investor sustaining the damage had his or her habitual residence when the damage occurred...” to be applicable. ${ }^{57}$ In addition, jurisdiction shall lie with “...the Member State in which the investor sustaining the damage had his or her domicile when the damage occurred" according to the Amendment of Art. 35a para. 6 of the Committee of Legal Affairs. ${ }^{58}$

Despite this wide range of proposals to amend the Draft Proposal of the EU Commission, on November 27, 2012 negotiations in the European Parliament and the Council have reached a certain agreement on the accountability of rating agencies. ${ }^{59}$ According to this agreement “... an investor or issuer may claim damages from ... (an) agency for losses due to ... (an) infringement..." that an agency has committed, intentionally or with gross negligence (, any of the infringements listed as having an impact on a credit rating)”. ${ }^{60}$ The political text, however, has to be polished yet and will be put before Parliament to a plenary vote in January 2013.

\section{Main parameters of an effective liability rule in the rating sector}

In light of the dangers of an excessive liability of rating agencies to the capital markets and companies’ ability to raise capital, some careful analysis seems to be in order as to

\footnotetext{
${ }^{56}$ European Parliament, Committee on Economic and Monetary Affairs, Report on the proposal of August 23, 2012. for a regulation of the European Parliament and of the Council amending Regulation (EC) No 1060/2009 on credit rating agencies (COM(2011)0747 - C7-0420/2011 - 2011/0361(COD)), August 23, 2012, A7-0221/2012, p. 83 and 84, available at http://www.europarl.europa.eu/sides/getDoc.do?pubRef=-//EP//NONSGML+REPORT+A7-20120221+0+DOC+PDF+V0//EN.

${ }^{57}$ European Parliament, Committee on Economic and Monetary Affairs, Report on the proposal of August 23, 2012. for a regulation of the European Parliament and of the Council amending Regulation (EC) No 1060/2009 on credit rating agencies (COM(2011)0747 - C7-0420/2011 - 2011/0361(COD)), August 23, 2012, A7-0221/2012, p. 68, available at http://www.europarl.europa.eu/sides/getDoc.do?pubRef=-//EP//NONSGML+REPORT+A7-20120221+0+DOC+PDF+V0//EN.

${ }^{58}$ European Parliament, Committee on Economic and Monetary Affairs, Report on the proposal of August 23, 2012. for a regulation of the European Parliament and of the Council amending Regulation (EC) No 1060/2009 on credit rating agencies (COM(2011)0747 - C7-0420/2011 - 2011/0361(COD)), August 23, 2012, A7-0221/2012, p. 85, available at http://www.europarl.europa.eu/sides/getDoc.do?pubRef=-//EP//NONSGML+REPORT+A7-20120221+0+DOC+PDF+V0//EN.

${ }^{59}$ European Commission, Press Release: Statement by Commissioner Michel Barnier following the agreement in trilogue of new European rules to regulate credit rating agencies, Memo/12/911, Brussels, 27 November 2012, available at http://europa.eu/rapid/press-release_MEMO-12-911_en.htm.

${ }^{60}$ European Parliament, Press Release: Deal on stricter EU rules for sovereign debt ratings, REF. : 20121127IPR56742, Brussels, 28.11.2012.
} 
whether such a manipulation with capital markets eliminates more serious distortions resulting from flawed ratings. ${ }^{61}$

\section{A. Excessive liability versus immunity - The causation issue}

1. Dangers of excessive liability

Talking about market mechanisms, with regard to investors the point of departure of the analysis is the benefit the latter receive from ratings without payment under the issuer pay model. Therefore the question must be raised whether this has to be taken into account for the calculation of damages because some equivalence between liability and costs seems to be called for. In addition, ratings do not always necessarily lead to immediate financial loss on the part of the investor, as is the case if the issuer benefits from the flawed unjustifiably positive rating and receives a higher payment from the investor. Damages are different, when it comes to transactions in the secondary market which are influenced by flawed ratings. In these latter cases, the financial loss of the acquirer is compensated by the gain in the security price for the seller, so that the damage can be looked at as matter of redistribution rather than an actual loss of ressources. ${ }^{62}$ Therefore one may wonder whether to take into account these flawed ratings that from a macroeconomic point of view have not lead to a loss of value. It is true that the latter may result from the misallocation of capital and the deterioration of capital market integrity. ${ }^{63}$ These losses are, however, hardly quantifiable and therefore it seems unjustifiable to put them on one level with a loss of ressources because overdeterrence may result.

\section{Limits to immunity}

In light of these dangers of excessive liability, the privity limitations common in a lot of legal systems seem plausible. ${ }^{64}$ At first sight the same may hold true for the required proof of causation or reliance. At the same time, as has been seen at the example of the

\footnotetext{
${ }^{61}$ B. Haar, Haftung für fehlerhafte Ratings von Lehman-Zertifikaten - Ein neuer Baustein für ein verbessertes Regulierungsdesign im Ratingsektor? Neue Zeitschrift für Gesellschaftsrecht 2010, 1281, 1284.

${ }^{62}$ For this differentiation see T. Baums and C. Fischer, Haftung des Prospekt- und des Abschlussprüfers gegenüber den Anlegern, p. 25, 40, 47, in: F. Richter, A. Schüler and B. Schwetzler (eds.), Kapitalgeberansprüche, Marktwertorientierung und Unternehmenswert, Festschrift für Jochen Drukarczyk, 2003; from an economic perspective cf. J. Bigus and H.B. Schäfer, Die Haftung des Wirtschaftsprüfers am Primär- und Sekundärmarkt. Eine rechtsökonomische Analyse, 77 Zeitschrift für Betriebswirtschaft 19-49 (2007).

${ }^{63}$ H.B. Schäfer, Haftung für fehlerhafte Wertgutachten aus wirtschaftswissenschaftlicher Perspektive, 202 Archiv für die civilistische Praxis 809, 814 (2002).

${ }^{64}$ See above II.C.1. and 2.
} 
German case law on investor reliance, these requirements can eliminate liability altogether. Therefore a less onerous burden of proof may be justified. The general application of the fraud-on-the-market theory, however, may extend liability without reasonable bounds, even though capital market integrity may lie within the protective aim of the civil liability regime, as stated above. In addition, one may find this standard increasingly unconvincing, considering the growing evidence of systematic deviation of investor behavior from the rationality hypothesis. There are other ways to ease the burden of proof, though. A common basis to do so is by way of a presumption used in favor of investors sustaining damages as a result of false information to the effect that these investors would have taken a different investment decision in line with the correct information. ${ }^{65}$ To be sure, this presumption excludes the possibility of a decision conflict in case of correct information. ${ }^{66}$ Bringing this presumption to bear on the causation issue in liability cases of rating agencies and investors, one would have to alleviate the burden of proof for the latter, if they can show that there is no evidence of a decision conflict with regard to his investment decision.

\section{B. Liability Caps}

Another important parameter to arrive at a differentiated adjustment of liability in the rating sector could be the introduction of liability caps. At first sight one could consider to limit the damages eligible for compensation to the financial loss suffered by the investors in the primary market, whereas the loss resulting from redistribution in the secondary market would not have to be compensated. Over all this would allow a cap in the amount of the losses sustained on balance by the investment community. ${ }^{67}$ The implementation of this proposal is confronted with insurmountable difficulties because the loss would have to be claimed collectively by the investment community. ${ }^{68}$ Alternatively, one could also look at the loss of the issuer as a cap. This solution seems questionable, though, because the issuer's interests are contrary to the investors' with regard to the rating. Countervailing incentive effects would result and what would seem

\footnotetext{
${ }^{65}$ BGH BGHZ 61, 118; 123, 114; 124, 151, 159 f.; Neue Juristische Wochenschrift 1992, 2560; Neue Juristische Wochenschrift 1995, 1026; Zeitschrift für Wirtschafts- und Bankrecht 2006, 668; Zeitschrift für Wirtschaftsrecht 2007, 518, 521; Zeitschrift für Wirtschafts- und Bankrecht 2009, 1274; Zeitschrift für Wirtschafts- und Bankrecht 2011, 925, 927 and following.

${ }^{66}$ BGH, Zeitschrift für Wirtschafts- und Bankrecht 2011, 925, 928.

${ }^{67}$ See for this proposal J. Bigus and H.-B. Schäfer, Die Haftung des Wirtschaftsprüfers am Primär- und Sekundärmarkt. Eine rechtsökonomische Analyse, 77 Zeitschrift für Betriebswirtschaft 19, 36 (2007).

${ }^{68}$ C. Ott, Die Haftung von Wirtschaftsprüfern gegenüber Anlegern am Kapitalmarkt, p. 171, 181, in: T. Eger, J.Bigus, C. Ott and G. v. Wangenheim (eds.), Internationalisierung des Rechts und seine ökonomische Analyse, Festschr. f. H.-B. Schäfer (Gabler 2008).
} 
to be a loss for the investor, would be a contractually agreed performance with regard to the issuer.

In light of these difficulties of loss assessment and the dangers of excessive liability it seems plausible to try to tie the amount of damages to the amount of fees earned by the agencies. There has been a proposal to implement an earnings-based cap on liability and limit financial liability to cases of gross negligence. ${ }^{69}$ Another proposal forwarded by John Coffee is based on a modified form of strict liability for rating agencies that would cap obligations at a multiple of annual revenues. ${ }^{70}$ Another proposal calculates on the basis of a percentage of damages. ${ }^{71}$ The common flaw of these proposal lies in the arbitrariness of the determination of the cap they rely on.

If one considers the specific liability case in question, it appears plausible to look at the fees earned from the individual issue because it would be exaggerated to hold rating agencies liable for the full value of the issues they rate on a regular basis. The volume of issues rated by rating agencies goes far beyond the fees they earn. Considering the enormous harm to the capital market they can cause, higher liability caps may still be justified in cases of gross negligence of recklessness as they have become evident from the email correspondence published in the Summary Report of the Securities Exchange Commission in 2008. ${ }^{72}$ On the other hand, in day-to-day business damages in cases of simple negligence should not exceed the total fee. In fact, one might consider a cap based on the idea to disgorge the profits of the rating agency in these cases in order to avoid over-deterrence. There may still be the argument that this would lead to underdeterrence because such a cap is too low. If rating agencies, however, risk to lose entire

\footnotetext{
69 J. Manns, Rating Risk After the Subprime Mortgage Crisis: A User Fee Approach for Rating Agency Accountability, 87 N.C. L. Rev. 1011, 1076 (2009); S. Harper, Note. Credit-rating agencies deserve credit for the 2007-2008 financial crisis: an analysis of CRA liability following the enactment of the DoddFrank Act, 68 Wash. \& Lee L. Rev. 1925 (2011).

${ }^{70}$ F. Partnoy, Strict Liability for Gatekeepers: A Reply to Professor Coffee, 84 B.U. L.Rev. 365 (2004); S. Harper, Note. Credit-rating agencies deserve credit for the 2007-2008 financial crisis: an analysis of CRA liability following the enactment of the Dodd-Frank Act, 68 Wash. \& Lee L. Rev. 1925, 1969 (2011).

${ }^{71}$ F. Partnoy, Strict Liability for Gatekeepers: A Reply to Professor Coffee, 84 B.U. L.Rev. 365-366 (2004); S. Harper, Note. Credit-rating agencies deserve credit for the 2007-2008 financial crisis: an analysis of CRA liability following the enactment of the Dodd-Frank Act, 68 Wash. \& Lee L. Rev. 1925, 1969 (2011).

72 „Rating agencies continue to create an even bigger monster - the CDO market. Let‘s hope we are all wealthy and retired by the time this house of cards falters." Securities Exchange Commission, Summary Report of Issues Identified in the Commission Staff's Examinations of Select Credit Rating (July 2008) p. 12, available at (http://www.sec.gov/news/studies/2008/craexamination070808.pdf).
} 
fees for simple negligence, they will be more diligent, considering their high revenue generated from rating structured finance. ${ }^{73}$

The concept of disgorgement of profits seems to be a suitable basis to deal with the danger of excessive liability for a number of reasons. First of all, it is a well-known legal instrument of ex ante behavior control in US regulation of insider trading ${ }^{74}$ and in German antitrust ${ }^{75}$. It eases the burden of proof for causation and facilitates the determination of damages. ${ }^{76}$ On the other hand, the problems of more serious cases of false and misleading conduct may not adequately be dealt with and under-deterrence may result. Therefore some differentiation is in order that is clearly missing in the Draft Proposal of the European Commission. It seems that a lot needs to be done in Brussels yet to legislate an optimal liability concept.

\section{Summary}

Under most legal systems contractual liability of rating agencies is limited by doctrinal requirements of privity of contract. Tort claims are generally confronted with difficulties of proof relating to causation. Strict statutory expert liability, on the contrary, may lead to over-deterrence and result in a market freeze.

Art. 35a of the Draft Proposal of the EU Commission to Amend the Rating Agency Regulation introduces strict liability for rating agencies which is at odds with the aim to strengthen competition in the rating sector and could have a chilling effect on capital markets. That is why the reversal of the burden of proof is under discussion in the legislative process and has in part been alleviated. Furthermore, reference is now made to the member states' legal systems and jurisdictions.

The distinction between an actual loss in ressources in the primary market and a loss resulting from redistribution in the secondary market may lead to a more differentiated

\footnotetext{
${ }^{73}$ See e.g. E. Blair Smith, Bringing Down Wall Street as Ratings Let Loose Subprime Scourge, Bloomberg, September 24, 2008 (available at: http://www.bloomberg.com/apps/news?sid=ah839IWTLP9s\&pid=newsarchive).

74 Securities Exchange Act of 1934 § 16 (a), 15 U.S.C. § 78p.

75 § 34 Abs. 2 GWB (German Antitrust Act).

${ }^{76}$ For details cf. B. Haar, Nachhaltige Ratingqualität durch Gewinnabschöpfung? Zur Regulierung und ihrer Implementierung im Ratingsektor, 21 Zeitschrift für Bankrecht und Bankwirtschaft 177, 185 (2009); J.P. Hunt, Rating Agencies and the 'Worldwide Credit Crisis': The Limits of Reputation, the Insufficiency of Reform, and a Proposal for Improvement, 2009 Colum. Bus. L. Rev. 109, 207 (2009).
} 
analysis of the liability question. Presumptions in favor of the investor may help to overcome the insurmountable difficulties of proof relating to causation. Liability caps based on the concept of disgorgement of profits of the rating agencies may help to strike an adequate balance between the danger of macroeconomic harm created by reckless rating agencies and the threat of a market freeze resulting from over-deterrence. 